\title{
P01.24. Central processing by electroacupuncture of vasodepression and bradycardia reflex responses
}

\author{
S Tjen-A-Looi", P Li, J Longhurst \\ From International Research Congress on Integrative Medicine and Health 2012 \\ Portland, Oregon, USA. 15-18 May 2012
}

\section{Purpose}

Electroacupuncture (EA) at P5-6 reduces sympathoexcitatory blood pressure (BP) reflex responses. Gammaaminobutyric acid (GABA) receptors in the brainstem region rostral ventral lateral medulla (rVLM) contribute to modulation of sympathoexcitatory visceral reflexes during EA. Gastric distension in hypercapnic acidotic rats, by activating both sympathetic and vagal afferents, decreases $B P$ and heart rate $(\mathrm{HR})$ through a $\mathrm{GABA}_{\mathrm{A}}$ mechanism in the rVLM. This study investigated the hypothesis that EA modulates gastric induced hemodynamic depressor responses through actions in nuclei that process both sympathetic and parasympathetic outflow.

\section{Methods}

Anesthetized and hypercapnic acidotic induced rats were used to examine the central processing of the actions of EA. An unstressed 2-cm diameter latex balloon attached to a polyurethane tube was inserted into the stomach through the mouth and esophagus to induce gastric distention. Acupuncture needles were placed near the wrist at P5-6 acupoints for 30-min EA (2 Hz, 0.2-0.4 mA, $0.5 \mathrm{~ms}$ ).

\section{Results}

We observed repeatable decreases in BP and HR with gastric distention every $10 \mathrm{~min}$. Bilateral EA at P5-6 for $30 \mathrm{~min}$ reversed the hypotensive response from $-26 \pm 3$ to $-6 \pm 1 \mathrm{mmHg}$ and the bradycardia from $-35 \pm 11$ to -10 \pm 3 beats/min for over $70 \mathrm{~min}$. EA's action on decreased $\mathrm{BP}$ and $\mathrm{HR}$, respectively, was inhibited by microinjection of gabazine, a $\mathrm{GABA}_{\mathrm{A}}$ receptor antagonist, into the

University of California, Irvine, Irvine, USA
caudal-VLM (cVLM) or the nucleus ambiguus (NAmb). Gabazine microinjected into the rVLM reversed EA action on both depressor and bradycardia responses.

\section{Conclusion}

Thus, EA through $\mathrm{GABA}_{\mathrm{A}}$ receptor mechanisms modulates reflex sympathoinhibition and vagal excitation leading to cardiovascular depression through actions in the rVLM, cVLM and NAmb. These data indicate that EA can normalize elevated and depressed blood pressure.

Published: 12 June 2012

doi:10.1186/1472-6882-12-S1-P24

Cite this article as: Tjen-A-Looi et al:: P01.24. Central processing by electroacupuncture of vasodepression and bradycardia reflex responses. BMC Complementary and Alternative Medicine 2012 12(Suppl 1):P24.

Submit your next manuscript to BioMed Central and take full advantage of:

- Convenient online submission

- Thorough peer review

- No space constraints or color figure charges

- Immediate publication on acceptance

- Inclusion in PubMed, CAS, Scopus and Google Scholar

- Research which is freely available for redistribution 